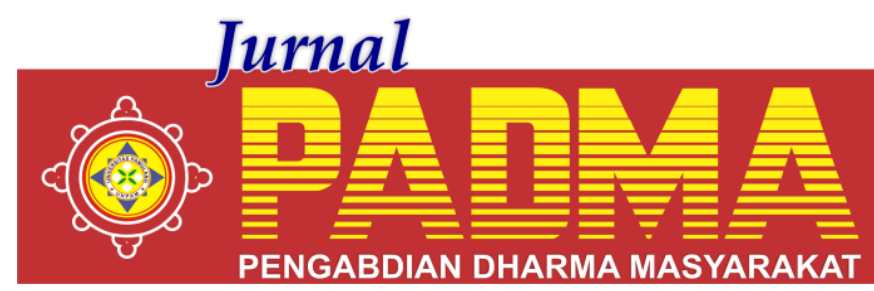

VOLUME 1, NOMOR 3, JULI 2021

\title{
MEMAHAMI PENTINGNYA MANAJEMEN PENGORGANISASIAN DALAM KARANG TARUNA
}

\author{
${ }^{1 *}$ Gilang Purwadi, 2 Dwi Chandra, ${ }^{3}$ Annisa Apriliani, ${ }^{4}$ Tia Oktaviani Yuliani, \\ 5Yunita Rosa Damayanti \\ Universitas Pamulang, Tangerang Selatan, Banten, Indonesia \\ *gilangpurwadi0307@gmail.com
}

\begin{abstract}
Abstrak
Karang Taruna merupakan wadah pengembangan generasi muda nonpartisan, yang tumbuh atas dasar kesadaran dan rasa tanggung jawab social dari, oleh dan untuk masyarakat khususnya generasi muda di Karang Taruna / Ikatan Remaja Masjid Rt.005 Rw.004 kel. Serua, Kec. Ciputat Kota Tangerang Selatan Banten. Sebagai organisasi social kepemudaan Karang Taruna / Organisasi Masjid merupakan wadah pembinaan dan pengembangan serta pemberdayaan dalam upaya mengembangkan kegiatan ekonomi produktif dengan pendayagunaan semua potensi yang tersedia di lingkungan sumber daya manusia.
\end{abstract}

Kata Kunci: Pengorganisasian

Abstract
Karang Taruna is a forum for the development of non-partisan young generations, who grow on the basis of awareness and a sense of social responsibility from, by and for the community, especially the young generation in the Youth Organization of the Youth Organization of the Mosque Rt.005 Rw.004 kel. Serua, Kec. Ciputat, South Tangerang City, Banten. As a youth social organization, Karang Taruna / Mosque Organization is a forum for guidance and development as well as empowerment in an effort to develop productive economic activities by utilizing all the potential available in the human resource environment.

Keywords: Organizing

\section{PENDAHULUAN}

Pengabdian masyarakat adalah suatu kegiatan yang bertujuan membantu masyarakat tertentu dalam beberapa aktivitas tanpa mengharapkan imbalan dalam bentuk apapun. Secara umum program ini dirancang oleh berbagai universitas atau institut yang ada di Indonesia begitu pula di Universitas Pamulang (UNPAM) untuk memberikan kontribusi nyata bagi bangsa Indonesia, khususnya dalam mengimplementasikan kadar lingkungan kepada Masyarakat".

Dalam kehidupan bersosialisasi karang taruna cukup berpengaruh bagi warga setempat Karang Taruna merupakan wadah pengembangan generasi muda nonpartisan, yang tumbuh atas dasar kesadaran dan rasa tanggung jawab sosial dari, oleh dan untuk masyarakat khususnya generasi muda di wilayah Desa/ Kelurahan atau komunitas sosial sederajat, yang terutama bergerak dibidang kesejahteraan sosial. Sebagai organisasi sosial kepemudaan Karang Taruna merupakan wadah pembinaan dan pengembangan serta pemberdayaan dalam upaya mengembangkan kegiatan ekonomi produktif dengan pendayagunaan semua potensi yang tersedia di lingkungan baik sumber daya manusia maupun sumber daya alam yang telah ada. Sebagai organisasi kepemudaan, Karang Taruna berpedoman pada Pedoman Dasar dan Pedoman Rumah Tangga di mana telah pula diatur tentang struktur pengurus dan masa jabatan di masing-masing wilayah mulai dari Desa/ Kelurahan sampai pada tingkat Nasional. Semua ini wujud dari pada regenerasi organisasi demi kelanjutan organisasi serta pembinaan anggota Karang Taruna baik dimasa sekarang maupun masa yang akan datang.

Kepedulian masyarakat terhadap perkembangan generasi muda guna sebagai penerus di kampung setempat menjadi hal yang harus di lakukan agar penerus nya 
mampu menggantikan yang terdahulu dalam beberapa kesiapan berbagai keperluan seperti acara di kampung, penyaluran bantuan social, kematian, kecelakaan

Permasalahan Organisasi cukup beragam dari mulai kurangnya koordinasi, pengkaderan mengatur organisasinya sendiri agar mampu berkembang sesuai yang di harapkan penulis ingin melakukan pengabdian masyarakat dengan tujuan menyadarkan dan membantu ekonomi warga sekitar yang dilakukan ini berjudul "

\section{Memahami Pentingnya Manajemen Pengoraganisasian dalam Karang Taruna".}

Karang Taruna adalah organisasi sosial kemasyarakatan sebagai wadah dan sarana pengembangan setiap anggota masyarakat yang tumbuh dan berkembang atas dasar kesadaran dan tanggung jawab sosial dari, oleh dan untuk masyarakat terutama generasi muda di wilayah desa/kelurahan terutama bergerak dibidang usaha kesejahteraan sosial. Sehingga diharapkan dengan adanya Karang Taruna, generasi muda dapat turut berpartisipasi dalam mengembangkan dan memajukan masyarakat dari berbagai bidang yang ada. Selain itu juga untuk mengembangkan berbagai potensi yang ada di masyarakat dan generasi muda untuk dapat dioptimalkan dan dikembangkan untuk memajukan pribadi, masyarakat, bangsa dan negara.

Organisasi ini biasanya tumbuh atas dasar kesadaran dan rasa tanggung jawab sosial generasi muda dan anak muda yang giat bergerak di bidang kesejahteraan sosial. Pada era globalisasi ini, Karang Taruna di masyarakat sudah mulai berkurang khususnya di kalangan generasi muda. Keberadaan Karang Taruna sendiri masih minim, kinerja Karang Taruna masih dipertanyakan. Dapat kita lihat, Karang Taruna hanya terdapat di desa dan kota pinggiran. Hal itu diperkuat dengan pengelolaan yang tidak maksimal dan kurangnya sarana dan prasarana serta program-program yang tidak dilaksanakan dengan baik. Keadaan itu dikarenakan sumber daya manusia yang kurang terlatih, kurang pengetahuan dan kurang pengalaman serta kurangnya dukungan kegiatan Karang Taruna secara optimal oleh pemerintah. Apabila ditinjau lebih lanjut, dengan berkembangnya Karang Taruna di masyarakat luas atau bahkan di seluruh Indonesia akan sangat membantu tugas pemerintah untuk mewujudkan kesejahteraan sosial di Indonesia yang merata dan menyeluruh.

Pengelolaan lingkungan karang taruna adalah upaya terpadu dalam melaakukan pemanfaatan, penataan, pemeliharaan, pengawasan, pengendalian dan pengembangan lingkungan hidup, sehingga pelestarian potensi sumber daya manusia dapat tetap dipertahankan, dan pencemaran atau kerusakan lingkungan dapat dicegah. Perwujudan dari usaha tersebut antara lain dengan menerapkan teknologi yang tepat dan sesuai dengan kondisi lingkungan sekitar.

Untuk itu berbagai prinsip yang dipakai untuk pengelolaan lingkungan pergaulan antara lain :

a. Preventif (pencegahan), didasarkan atas prinsip untuk mencegah timbulnya dampak yang tidak diinginkan, dengan mengenali secara dini kemungkinan timbulnya dampak negative pergaulan, sehingga rencana pencegahan dapat disiapkan sebelumnya.

Beberapa contoh dalam penerapan prinsip ini adalah melaksanakan AMDAL secara baik dan benar, pemanfaatan sumber daya alam dengan efisien sesuai potensinya.

b. Kuratif (penanggulangan), didasarkan atas prinsip menanggulangi dampak yang terjadi atau yang diperkirakan akan terjadi, namun karena keterbatasan teknologi, hal tesebut tidak dapat dihindari.

Hal ini dilakukan dengan pemantauan terhadap pergaulan lingkungan sekitar yang terkena dampak seperti budaya dari lingkungan luar.

Apabila hasil pemantauan lingkungan mendeteksi adanya perubahan lingkungan, maka perlu ditelusuri penyebab/sumber dampaknya, dikaji pengaruhnya, serta diupayakan menurunnya kadar pencemaran yang timbul.

Rencana pengelolaan Organisasi, harus dilakukan dengan mempertimbangkan pendekatan generasi muda, yang kemudian harus dapat dipadukan dengan pendekatan 
Organisasi, serta pendekatan institusional sebagai berikut :

1. Organisasi harus mempunyai tujuan akhir.

2. Tujuan-tujuan tersebut harus diidentifikasi dan ditetapkan dengan baik agar dapat dimengerti.

3. Tujuan-tujuan tersebut harus sedikit saja agar mudah dikelola.

4. Harus ada consensus atau (kesepakatan umum mengenai tujuan-tujuan tersebut),

Oleh karena itu empat asumsi diatas menyatakan bahwa keefektifan sebuah organisasi harus dinilai dengan pencapaian tujuan ketimbang caranya.

Beberapa permasalahan dalam pendekatan ini antara lain adalah :

1. Apa yang dinyatakan secara resmi oleh sebuah organisasi sebagai suatu tujuan tidak selalu mencerminkan tujuan yang sebenarnya.

2. Tujuan jangka pendek sering kali berbeda dengan tujuan jangka panjangnya.

3. Organisasi yang memiliki tujuan majemuk akan menciptakan kesulitan.

\section{METODE}

Metode yang digunakan dalam Pengabdian Kepada Masyarakat (PKM) ini yaitu metode presentasi atau edukasi bersama anggota karang taruna dengan menjelaskan materi menggunakan metode digital.

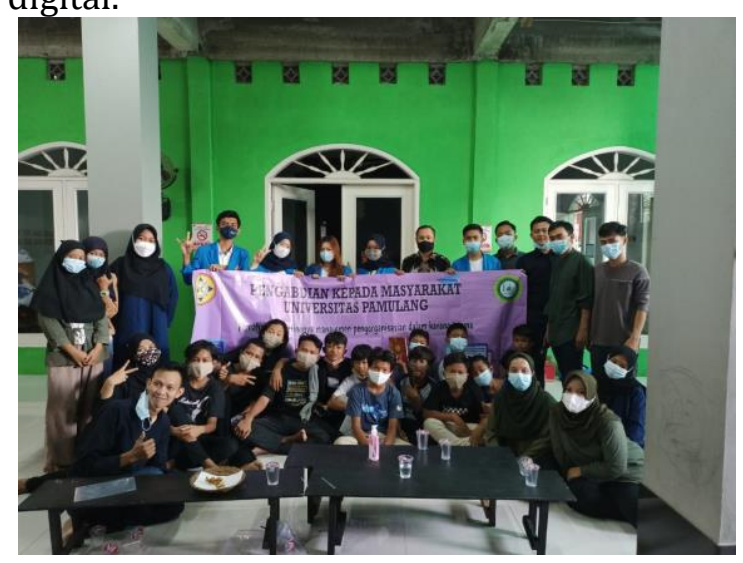

Gambar 1. Foto Panitia PKM

Solusi yang dapat di terapkan yaitu kita sebagai masyarakat indonesia yang baik kita harus bisa menjaga lingkungan kita sendiri dengan baik agar terhindar dari pengaruh negative dari lingkungan lain yang tidak diinginkan dan dapat menyebabkan rusaknya generasi muda jika metode ini tidak diterapkan.

\section{HASIL DAN PEMBAHASAN}

Tempat pelaksanaan kegiatan Pengabdian Kepada Masyarakat (PKM) di Karang Taruna Kp Serua Ciputat Tangerang Selatan. Adapun waktu pelaksanaan dari kegiatan Pengabdian Kepada Masyarakat di laksanakan pada tanggal 24 Maret 2021 hingga 26 Maret 2021:

Materi penyuluhan adalah manajemen pengoraganisasian dalam karang taruna di ligkungan warga sekitar Tujuan: Dari rumusan masalah diatas dapat ditarik sebuah tujuan yaitu, untuk meningkatkan kesadaran masyarakat akan pentingnya manajemen pengoraganisasian dalam karang taruna lingkungan dengan baik.

Kegiatan pengabdian ini dilakukan di Jl Masjid nurul hikmah Kp Maruga Rt 005 Rw 004 Kel serua Kec Ciputat Kota tangerang selatan Banten

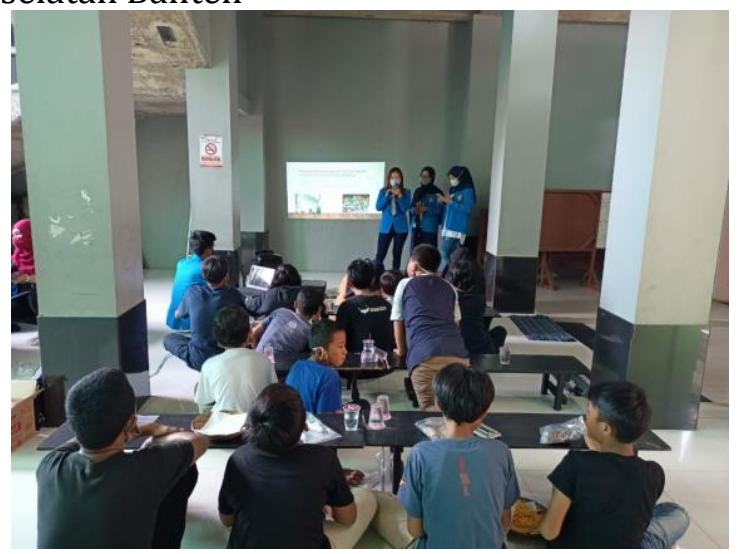

Gambar 2. Kegiatan PKM

Persiapan kegiatan ini berupa penentuan materi yang cocok untuk disampaikan kepada seluruh anggota pengurus masjid / kampung wilayah sekitar dengan judul manajemen pengoraganisasian dalam karang taruna.

masyarakat ini diharapkan dapat digunakan sebagai bahan pertimbangan bagi masyarakat dalam mengatasi permasalahan yang terjadi di lingkungan sekitar, sehingga dapat membantu memberikan pemahaman kepada masyarakat yang mempunyai kepedulian terhadap pengorgaisasian sekitar.

\section{PENUTUP}

Setelah melakukan dan menganalisis data maka kami dalam tahapan ini akan menyimpulkan beberapa hal sebagai berikut: 1. Kondisi lingkungan hidup di pemukiman warga pada saat ini secara keseluruhan 
sudah cukup baik. Namun kesadaran masyarakat untuk menjaga lingkungan hidup perlu ditingkatkan, karena semua warga kampus mempunyai hak dan kewajiban yang sama dalam menjaga, memelihara dan melestarikan lingkungan disekitar kampus agar tetap terjaga, terpelihara dan bebas dari polusi. Sehingga terciptanya lingkungan yang nyamanm dan asri.

2. Organisasi karang taruna memiliki peranan besar dalam meningkatkan kesadaran lingkungan hidup pada masyarakat. Hal ini terlihat dalam program-program yang dijalankan, organisasi pecinta alam juga turut berkontribusi dalam kegiatan lingkungan.

3. Program yang dijalankan organisasi karang taruna dalam meningkatkan kesadaran lingkungan hidup meliputi bakti sosial, seminar, penyuluhan, pembinaan serta program-program lainnya yang berkaitan dengan pentingnya menjaga lingkungan hidup.

4. Hambatan yang dihadapi organisasi karang taruna dalam meningkatkan kesadaran lingkungan hidup dibagi menjadi dua, yaitu: faktor internal dan faktor eksternal. Faktor internal kurangnya kesadaran anggota karang taruna itu sendiri akan tugas dan peran masing-masing. Sedangkan faktor eksternal, kurangnya partisipasi masyarakat dalam program yang berhubungan dengan lingkungan karena kesibukan pekerjaan serta kurangnya sosialisasi secara merata mengenai pentingnya manajemen organisasi dalam karang taruna.

\section{DAFTAR PUSTAKA}

Aviliani, R dan Wilfridus, L. 1997. Membangun Kepuasan Pelanggan Melalui Kualitas Pelayanan. Usahawan, No.5

Djarwanto. 1996. Mengenal beberapa Uji Statistik dalam Penelitian.Yogyakarta: Liberti.Djarwanto, PS dan Subagyo,

Ghozali, Imam. 2000. Aplikasi Analisis Multivariate dengan SPSS. Semarang: Universitas Diponegoro.

2005. Aplikasi Analisis Multivariate dengan SPSS. Semarang: Universitas Diponegoro.
2006.Aplikasi Analisis Multivariate denganSPSS. Semarang: Universitas Diponegoro

Gunartin, G., Mulyanto, E., \& Sunarsi, D. (2020). The Role Analysis of Waste Bank in Improving the Community's Creative Economy (Study at Ketumbar Pamulang Waste Bank). Budapest International Research and Critics Institute (BIRCI-Journal): Humanities and Social Sciences, 3(4), 3262-3269.

Nurjaya, N., Sunarsi, D., Effendy, A. A., Teriyan, A., \& Gunartin, G. (2021). Pengaruh Etos Kerja Dan Disiplin Kerja Terhadap Kinerja Pegawai Pada Dinas Kehutanan Dan Perkebunan Kota Bogor. JENIUS (Jurnal Ilmiah Manajemen Sumber Daya Manusia), 4(2), 172-184.

Pangestu.1998. Statistik Induktif. Edisi IV. Yogyakarta: BPFE.Engel, et al. 2000. Perilaku Konsumen. Terj.F.X. Budianto. Jakarta : Binarupa Aksara.

Sunarsi, D., Akbar, I. R., Rozi, A., Khoiri, A., \& Salam, R. (2021). The Influence of Motivation and Work Discipline on Employee Performance at the Yogyakarta Tourism Service. Prosiding ICoGEMT, 1(1), 1-7. 